\title{
Financial Statements and Analysis, Taking Tencent as an Example
}

\author{
${ }^{*}$ Sijia Cai ${ }^{1,{ }^{*} \dagger}$ Yuxuan $\mathrm{Che}^{2,{ }^{*} \dagger}$ Dingyu Duan ${ }^{3,{ }^{*} \dagger}$ Haoyang $\mathrm{Liu}^{4,}{ }^{*} \dagger$ Yabei Yang ${ }^{5, \dagger}$ \\ ${ }^{1}$ City University of Hong Kong, Hong Kong 999077, China. \\ ${ }^{2}$ Dongbei University of Finance and Economics, Dalian, Liao Ning 116025, China; \\ ${ }^{3} X i$ 'an International Studies University, Xi'an, Shan Xi 710128, China; \\ ${ }^{4}$ Auburn University, Auburn, AL 36832, United States of America \\ ${ }^{5}$ Arizona State University, Tempe, AZ 85281, United States of America; \\ *Corresponding author's email: ${ }^{a}$ sijiacai2-c@my.cityu.edu.hk, ${ }^{b}$ yeseniawork@outlook.com, $2395074933 @ q q . c o m$, \\ d253463146@qq.com, ${ }^{e}$ sherly2012@outlook.com \\ These authors contributed equally.
}

\begin{abstract}
It is important to figure out a company's financial situation in order to analysis investment, borrowing, mergers and acquisitions, fraud surveys, and competitive intelligence. This is also beneficial when assessing the corporation financial situation itself. This paper studies a typical enterprise in the Internet industry, Tencent. By analyzing financial statements of Tencent in recent years, as well as business performance of Alibaba and Sina as they are the direct competitor of Tencent, the conclusion could be drawn that Tencent has greater potential in future as the main business income comes from value-added services. The second chart mainly analyzes the content and conclusion and the third chart provides the feasible strategy and suggestions linked to certain issues identified. Through this study, it is possible to make a role in Tencent or other Internet enterprise as well as making contribution on healthier industry development.
\end{abstract}

Keywords: Financial analysis, Corporation, Assets and Liabilities.

\section{INTRODUCTION}

In modern conditions, financial statements are the most complete, objective and reliable information base, based on which one can form an opinion on the property and financial position of a company [1]. In accordance with the legislation, the accounting financial statements are an open source of information, and its composition, content and presentation forms are unified by basic parameters, it becomes possible to develop standard methods to read and analyze it [2]. The essence of financial statements' analysis from the position of a user is to review and evaluate the information in the reporting to obtain reliable conclusions about the past state of an organization aiming at foreseeing its functioning in the future. Evaluation of financial statements is a process by which the past and current financial position and performance of the company are assessed. Because of financial statements' analysis, the company's most important characteristics are also determined, which testify, in particular, about its success or the risk of bankruptcy [3]. For different users, in terms of the scale of its implementation, the analysis of financial statements depends on a specific goal. At the same time, the analysis and direction of work while analyzing financial statements can be different. Therefore, company's financial statements can be useful for different interested parties [4]. Corporate profitability is on the minds of many stakeholders. Figuring out the financial health of a company is instrumental for investment, lending, mergers and acquisitions, fraud investigation, and competitive intelligence. It is also beneficial when evaluating the state of your own company's financial position. Financial analysis could simply be to support a class project. One key element in determining corporate profitability and financial health involves ratios. Ratios can give researchers insights into profitability, liquidity, finances, investment, and management [5]. Financial analysis begins with reading financial statements, which is a crucial skill for principal investigators managing research projects. Financial reporting allows 
communication with shareholders and potential investors to evaluate a company's state and ultimately guide their involvement in the company. Typically, this skill would be essential for a manager in a for-profit company to deduce the condition of a company or any project [6]. Financial analysis is particularly important for the development of an enterprise. What's more, evaluating the results of a marketing tool or project, it is very important to conduct empirical analysis through statements currently, technology of smart phones is rapidly developing and the continuous expansion of the game market, in this context, market strategies analysis play a very important role [7]. Investment is an important source of a company's income. When making investment decisions, the target company's business cycle also plays an important role in the decision [8]. For Chinese big three internet companies, Baidu, Alibaba, and Tencent have turned to capital-intensive mergers and acquisitions to consolidate their influence. While each company bases its operation on its core business-e.g., Tencent on value added content and online games - eash is now striving to diversify by investing in companies in other areas [9]. In research of international internet companies, one of the results reported suggest that "irrational exuberance in capital markets did not lead to managers in typical Internet companies to overinvest in growth, except in firms with unusually large cash balances" [10]. The next part of this paper will take Tencent's financial situation in recent years as an example to analyze Tencent's financial situation.

\section{METHOD}

\subsection{General methods introduction}

In order to better understand the data collected and to conduct efficient analysis on Tencent's financial statements, this study has adopted several classical research methods in this research, which are literature survey method, comparative analysis method, quantitative analysis method and case study method.

\subsubsection{Literature survey}

Literature survey is one of the basic as well as efficient research methods that commonly used by researchers. Generally speaking, it means that researchers look for what they want from all kinds of sources, learn from the work and results from other people and then formed their own ideas based on that. With the limited time and resources, it is impossible for us to know every detail about Tencent and other enterprises. Therefore, literature survey method has been adopted in the study of Tencent's case. This is the first kind of scientific method that have been applied.

\subsubsection{Comparative analysis}

Also known as comparative analysis method or comparative analysis method, it is another method that useful for the analysis. It is an analysis method to show the unique characteristics as well as of one thing through the differences between it and others that have close relationship with it or similar to it. This study conducted a competitive analysis and compare Tencent's financial reports with its major competitors who has business overlap with it such as SINA and Alibaba. That is the adoption of comparative analysis.

\subsubsection{Quantitative Analysis}

It is a mathematical method mainly used to analyze the quantitative characteristics, quantitative relations and quantitative changes of things, especially for social phenomenon. For business management, it can also be applied to financial statements such as balance sheets or income statements to help to measure the performance of enterprises and make it clearer to be viewed by people who concern about it. The function of quantitative analysis is to reveal and describe the interaction and development trend of social phenomena or the corporation. So that's why this method is used in the study.

\subsubsection{Case Analysis Method}

This is a scientific research method that first developed by the Harvard University and have be adopted through the whole study. Case analysis method requires researchers to pick up one identical case or what has been called sample from the things or area that they want to study. Then they study the case itself and find out the common things or general rules from the case and applied it to others. That's what this research wants to do by using Tencent as an example to study all the Internet enterprises.

These are some of the important methods that have been adopted in the analysis of the Tencent's case. This paper uses these methods to analyze Tencent's financial situation, research Tencent's development strategy, and give constructive suggestions on Tencent's future development.

\subsection{The design of research}

This paper comprehensively used methods above and the research will be carried out in following mind steps as shown in Figure 1.

Firstly, it identified research topic and decided the Internet corporations to be this topic. Then, it searched and read all the references materials that have been found and then brainstormed on what this study needs 


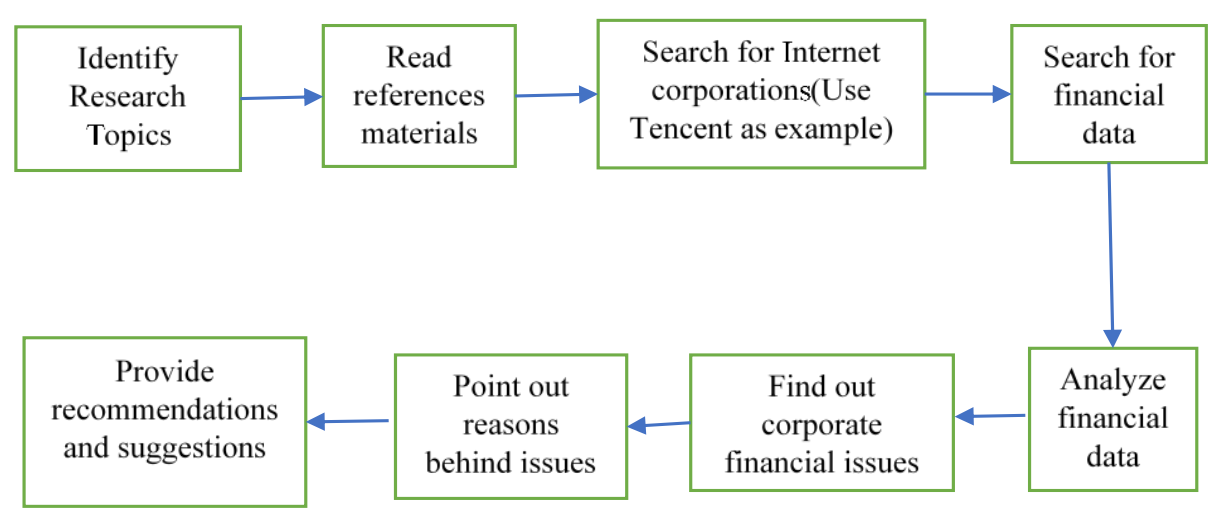

Figure 1. Flowchart of financial statement analysis research

to cover on the paper. Next, it took Tencent as example, searched for its published financial data to support this research paper and make it more credible. Finally, it has been found out some issues that Tencent and shareholders may concern about, pointed them out and use what have been learned to provide some recommendations and suggestions based on them. It is the idea and the whole design of this research.

\subsection{Typical financial indicators}

\subsubsection{Assets and liabilities}

Reflecting the acquisition or formation of the funds of enterprises and institutions is the asset, reflecting the application of funds and the existence of the liabilities. Modern capitalist enterprises and banks generally adopt asset and liabilities balanced forms in the balance sheet reflect a certain date (such as the end of the month, the end of the year, the end of the year). The asset liabilities are quite important to the company's analysis.

\subsubsection{Current assets}

It refers to the assets that can be realized or applied within an operating cycle of one year or more than one year, and it is an indispensable part of the assets of an enterprise. In the transition of turnover, current assets start from the form of money, change its form in turn, and finally return to the form of money (monetary funds $\rightarrow$ reserve funds, fixed funds $\rightarrow$ production funds $\rightarrow$ finished product funds $\rightarrow$ monetary funds). All forms of funds are closely integrated with production and circulation, with fast turnover speed and strong liquidity. The analysis of liquidity is an important way to study the cash flow and daily capital turnover ability of enterprises

\subsubsection{Cash and cash equivalent reserve}

Cash reserves refer to assets that can be obtained in a short period of time during cash, which is actually referring to two different types of financial assets. Cash reserves may refer to balances in checks and savings accounts or other short-term bank deposits that can be accessed can also include any short-term investment with high fluidity, such as monetary market tools.

When cash is required, there can be at least some cash reserves in most enterprises in a short period of time. This is important because these reserves meet the relatively easily sustained expenses. Enterprises reserve reserves in a special fund is not rare, such as the Emergency Fund or Emergency Fund, effectively created a resource that can be used in some unexpected expenses in the company.

\subsubsection{Net assets}

It refers to the net amount of total assets minus liabilities of an enterprise. It is equal to the balance of all assets minus all liabilities of the enterprise. Belong to owner's equity. Net assets are the owner's equity in the balance sheet. It is an asset that belongs to the enterprise and can be disposed of freely. It consists of two parts, one part is the initial investment of the enterprise, including the premium part; the other part is created in the operation of the enterprise, including the donated assets. Net assets are the own capital of a company, and for a joint stock company, net assets are the property owned by shareholders. It is now commonly known as shareholders' equity, and net assets are total assets minus the company's external liabilities. 


\section{RESULTS AND DISCUSSION}

\subsection{Gross profit margin analysis}

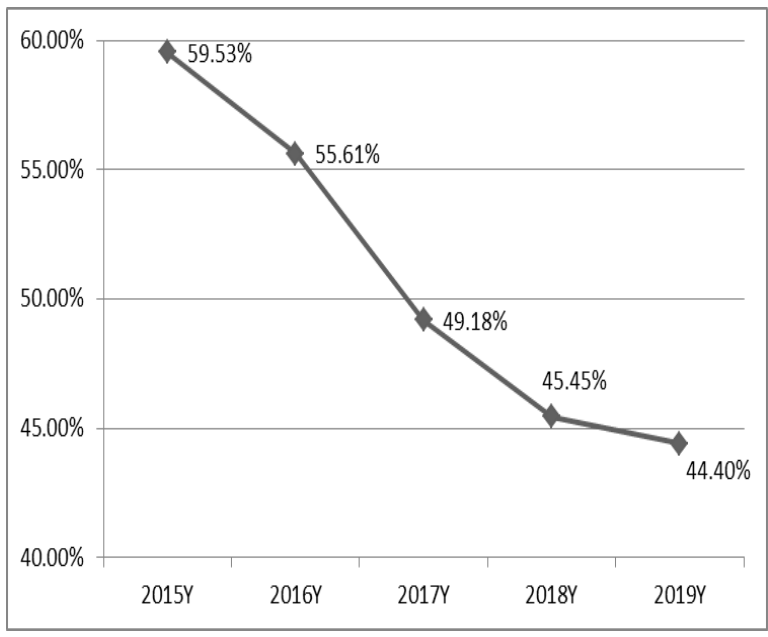

Figure 2. Tencent gross profit margin from 2015 to 2019

As shown in Figure 2, to reach the profitability trend, this study calculates the gross profit margin for recent five years, which is calculated by gross profit/sales. From the broken-line graph above, it shows a dynamic down slope trend from 2015 to 2019 from $59.53 \%$ to $44.40 \%$, which may decrease the confidence of existing and potential investors. This may due to large financial commitment in transaction cost, employee benefit and content cost.

\subsection{Historical analysis in statement of comprehensive income}

As shown in Table 1, In the other side, Tencent shows a robust profit that increase $19.88 \%$ as well as total income increased $20.66 \%$ during 2019 accounting period. As the separation between "Fintech and Business Services" and "Others" segment as well as the specialized operation in cloud service, payment and other enterprise-facing activities, the Fintech and Business Service revenue increase $38.58 \%$ comparing to 2018 fiscal year. Interest incomes increase from RMB 4569 million to RMB 6314 million, which mainly arise from increasing bank deposits during Coronavirus19 period. Besides, It shows that general and administrative cost increase significantly about $28.72 \%$. This may cause by more transaction cost on bank handing fees and more employee benefits expenses for motivating IT staff on research and development project, which costs from 22936 million in 2018 to 30387 million currently. Under the pressure of $R \& D$ in cloud service, the borrowing size increased, which significantly increase the finance cost about $63.05 \%$ in short period, but the financing decision may increase the shareholder's wealth in long-term. It is worth noting that the sharing profit (or loss) to joint venture or associate is decreased $213.05 \%$, making it from positive to negative. The inefficiency of invested company makes the group undertakes high loss. However, the income tax expense decreased RMB 970 million, which may cause by the tax advantage policy in High and New Technology Enterprise of $15 \%$ tax rate in PRC mainland.

Table 1. The trend of key financial data in Tencent's statement of comprehensive income from 2018 to 2019

\begin{tabular}{|c|c|c|c|c|}
\hline & 2019 & 2018 & Change of million & $\begin{array}{l}\text { Percentage } \\
\text { change }\end{array}$ \\
\hline & RMB Million & RMB Million & RMB Million & $\%$ \\
\hline $\begin{array}{l}\text { FinTech and business } \\
\text { services }\end{array}$ & 101,355 & 73,138 & 28,217 & $38.58 \%$ \\
\hline Interest income & 6,314 & 4,569 & 1,745 & $38.19 \%$ \\
\hline Total revenue & 377,289 & 312,694 & 64,595 & $20.66 \%$ \\
\hline $\begin{array}{l}\text { General and administrative } \\
\text { expenses }\end{array}$ & 53,446 & 41,522 & 11,924 & $28.72 \%$ \\
\hline Finance costs, net & 7,613 & 4,669 & 2,944 & $63.05 \%$ \\
\hline $\begin{array}{l}\text { Share of (loss)/profit of } \\
\text { associates and joint ventures, } \\
\text { net }\end{array}$ & 1,681 & 1,487 & 3,168 & $-213.05 \%$ \\
\hline Income tax expense & $(13,512)$ & $(14,482)$ & 970 & $-6.70 \%$ \\
\hline Profit for the year & 95,888 & 79,984 & 15,904 & $19.88 \%$ \\
\hline
\end{tabular}




\subsection{Profitability ratio analysis}

Table 2. The trend of Tencent's profitability ratio from 2018 to 2019

\begin{tabular}{lll}
\hline & $\mathbf{2 0 1 9 Y}$ & $\mathbf{2 0 1 8 Y}$ \\
\hline Profit margin & $44.40 \%$ & $45.45 \%$ \\
Asset turnover & 0.45 times & 0.49 times \\
$\begin{array}{l}\text { Return on assets } \\
\text { Return on common } \\
\text { stockholder's } \\
\text { equity }\end{array}$ & $11.43 \%$ & $12.52 \%$ \\
$\begin{array}{l}\text { Earnings per share } \\
\begin{array}{l}\text { Average price- } \\
\text { earnings ratio }\end{array}\end{array}$ & $9.87 \mathrm{RMB}$ & $8.34 \mathrm{RMB}$ \\
$\begin{array}{l}\text { Payout ratio } \\
\text { Pan }\end{array}$ & $8.66 \%$ & $25.26 \%$ \\
\hline
\end{tabular}

From the ratio analysis, it shows a down trend on operational performance. By calculation, a slight decrease occurs in profit margin ratio from $25.58 \%$ to $25.42 \%$, which means Tencent is facing problem in cost cutting and new project investment may scarify shortterm interest. Return on assets slightly decrease from $12.52 \%$ to $11.43 \%$ as well as the assets turnover rate is from 0.49 times to 0.45 times, which means the efficiency of employing recourses is decrease. Tencent need to enhance the talent management to develop the competence of staffs and senior management to cope with new strategy. Giving to more borrowing capital to support the cloud service investment, return on common stockholder's equity decrease from $25.26 \%$ to $22.69 \%$. Although Tencent is facing such operating dilemma, the EPS is increasing as the capital structure is more tend to debt finance, the residual value to shareholders is more. The average $\mathrm{P} / \mathrm{E}$ ratio is 33.78 , which is facing a decreasing trend from 2018 accounting period influenced by economical environmental change in China. To increase the confidence of the shareholders, Tencent makes friendly dividend policy and increase payout ratio from $8.47 \%$ in 2018 to $8.66 \%$ in 2019 accounting period, which is also helpful as a signal to capital market and increase shares price.

\subsection{Competitor Analysis}

Table 3. Major Business Operating Status of Tencent, Sina and Alibaba in 2019 (million RMB/million users)

\begin{tabular}{llll}
\hline & Tencent & Sina & Alibaba \\
\hline $\begin{array}{l}\text { Operating } \\
\text { revenue }\end{array}$ & 377,289 & $14,028.79$ & 376,844 \\
$\begin{array}{l}\text { Major } \\
\text { income }\end{array}$ & 199,991 & 5,495 & 247,615 \\
$\begin{array}{l}\text { Profit or } \\
\text { loss }\end{array}$ & 95,888 & -457.52 & 80,234 \\
\hline
\end{tabular}

\begin{tabular}{llll}
\hline MAUs & 1164.8 & 462 & 721 \\
\hline
\end{tabular}

In 2019, the major revenue sources for Alibaba, Sina and Tencent were commercial retail services, advertising services and value-added services in China, respectively, the data is shown in Figure 2. In 2019, Alibaba's advertising revenue was far ahead at 72.073 billion yuan, Tencent's at 29.809 billion yuan, and Sina's advertising revenue, though not more than 10 billion yuan, remained the main source of the company's revenue. In terms of user numbers, Tencent is far ahead and still has huge growth potential, while Sina will be at a relative disadvantage due to its limited number of active users. It is clear that the income difference is caused by the company's business scope and the number of active users. Compared with Sina, Tencent and Alibaba, the business system of Tencent is more complete and richer. Compared with Alibaba and Tencent, Tencent has more customers, so Tencent has the basis for making profits.

Table 4. Financial ratios of Tencent, Sina, and Alibaba in 2019

\begin{tabular}{llll}
\hline & Tencent & Sina & Alibaba \\
\hline ROE & $21.3 \%$ & $-2.6 \%$ & $16.4 \%$ \\
ROA & $11.8 \%$ & $-1.4 \%$ & $11.5 \%$ \\
P/E ratio & 48.76 & Negative & 28.11 \\
Debt ratio & $45.7 \%$ & $48.9 \%$ & $34.3 \%$ \\
Cash ratio & $19.7 \%$ & $36.4 \%$ & $28.3 \%$ \\
$\begin{array}{l}\text { Current } \\
\text { ratio }\end{array}$ & $123.1 \%$ & $265.3 \%$ & $166.9 \%$ \\
$\begin{array}{l}\text { Gross } \\
\text { profit } \\
\text { margin }\end{array}$ & $46 \%$ & $74.6 \%$ & $42.9 \%$ \\
$\begin{array}{l}\text { Profit ratio } \\
\text { EPS }\end{array}$ & $26.4 \%$ & $12.7 \%$ & $16.5 \%$ \\
$\begin{array}{l}\text { Total assets } \\
\text { turnover }\end{array}$ & 0.42 & -1.43 & 8.72 \\
$\begin{array}{l}\text { Receivable } \\
\text { turnover }\end{array}$ & 10.7 & 0.29 & 0.43 \\
$\begin{array}{l}\text { Goodwill } \\
\text { Short-term } \\
\text { debt }\end{array}$ & $93.456 \mathrm{billion}$ & 0 & $54.1 \mathrm{billion}$ \\
\hline
\end{tabular}

All three companies are in good cash flow positions. Of the three, Tencent and Alibaba have the greatest growth potential. By comparing the net interest rate, it can be seen that Tencent and Alibaba have rich after-tax profits, while Sina is in the red. By comparing the ROE, Tencent has the highest return, even beating Buffett's 
return.In terms of debt paying ability, Tencent's debt paying ability is the best, but the other two companies are not bad, even if there is a debt dispute can quickly repay.

Through checking the financial statements of the three enterprises, it can be found that the goodwill value of Alibaba is too high, accounting for $17.9 \%$ of the total assets, while Tencent's goodwill accounting for $9.7 \%$. Excessive goodwill means that the company buys assets at too high a premium and there is a risk of asset depreciation. However, the accounts receivable of Tencent Holdings and Sina in the total assets of the company have increased sharply in the past five years, there is a risk of accounting. Tencent's leverage multiple is 1.89 , higher than the industry median of 1.29 .

Tencent Holdings' recent five-year ROE has changed to $21.3 \%$ from $25.9 \%$, mainly due to a change in net profit margin. Alibaba's ROE level has not changed significantly in the past five years. By comparison, Tencent and Alibaba are far bigger than Sina in terms of market size and profitability. Compared with Tencent and Alibaba, the e-commerce invested by Tencent is not exclusive to Tencent, and Alibaba Group's e-commerce brand is an internal product of the group. Moreover, the income brought by club software for Tencent is not high, so Tencent should make full use of its existing resources to improve its income. Of the three, Tencent Holdings has the greatest growth potential.

Through the business model of Tencent, it could be understood that the main business income of Tencent comes from value-added services. Tencent can leverage its existing user resources and boost its revenue by offering other products that attract users.

\section{CONCLUSION}

Taking Tencent as an example, this paper studies the financial statements, analyzes the problems (lists the problems), points out the causes (lists the reasons), and finally puts forward some opinions or strategies to solve the problems (lists the strategies or opinions). Hopefully these strategies will play a positive role for Tencent or other Internet industries.

\section{REFERENCES}

[1] Thalassinos, I.E. and Liapis, K. 2014. Segmental financial reporting and the internationalization of the banking sector. Chapter book in, Risk Management: Strategies for Economic Development and Challenges in the Financial System, (eds), D. Milos Sprcic, Nova Publishers, 221-255, ISBN: 978-163321539-9; $978-$ 163321496-5.
[2] Suryanto, T., Thalassinos, I.E. 2017. Cultural ethics and consequences in whistle-blowing among professional accountants: An empirical analysis. Journal of Applied Economic Sciences, 12(6), $1725-1731$.

[3] Izuymov, I.V., Liman, I.A., Korenkova, S.I., Sadykova, H.N., Ignatova, Y.V., Bogdanova, J.Z. 2017. Economic and legal review of pretrial warning of insolvency in foreign legislation. Man in India, 97(20), 475-493.

[4] Osadchy, E. A., et al. "Financial statements of a company as an information base for decisionmaking in a transforming economy." (2018).

[5] Ojala, Marydee. "Financial Ratio Analysis for Companies and Industries." Online Searcher, vol. 45, no. 2, Mar. 2021, p. 39. EBSCOhost, search.ebscohost.com/login.aspx?direct=true $\& d b=$ edsggo\&AN=edsgcl.654815375\&site $=$ eds live $\&$ scope $=$ site .

[6] K. Prabakar, "Financial Analysis for Principal Investigators of Nonprofit Research," in IEEE Engineering Management Review, vol. 48, no. 4, pp. 17-19, 1 Fourthquarter,Dec. 2020, doi: 10.1109/EMR.2020.3036042.

[7] Dandong Shen, "Analysis on Marketing Strategies of Tencent Games-Take Honor of Kings as an Example", E3S Web of Conferences, vol.235, no.03028, 2021, NETID 2020, https://doi.org/10.1051/e3sconf/202123503028

[8] Linda Canina, Steven A. Carvell, Qingzhong Ma, Andrey D. Ukhov, "Business cycle and asset valuation in the gaming industry", Journal of Business Research, Volume 66, Issue 9, 2013, pp. 1689-1695, https://doi.org/10.1016/j.jbusres.2012.12.016.

[9] Lianrui Jia, Dwayne Winseck, "The political economy of Chinese internet companies: Financialization, concentration, and capitalization", the International Communication Gazette, 2018, Vol. 80(1) 30-59 The Author(s) 2018 Reprints and permissions:

sagepub.co.uk/journalsPermissions.nav

DOI: $10.1177 / 1748048517742783$

journals.sagepub.com/home/gaz

[10] Thomas R. Eisenmann, 'Internet Companies' Growth Strategies: Determinants of Investment Intensity and Long- Term Performance", Strategic Management Journal, Vol. 27, No. 12 (Dec. 2006), pp. 1183-1204, Stable URL: https://www.jstor.org/stable/20142407. 